\title{
Problematika Wakaf dan Penyelesaiannya di Pesantren Al-Falah Limboto Barat Kabupaten Gorontalo
}

\author{
Tarnima Zakiyah, Abdur Rahman Adi Saputera
}

MAN 1 Boalemo, IAIN Sultan Amai Gorontalo

Email: tarnima.zakiah@gmail.com; adisaputrabd@gmail.com

\begin{abstract}
This study aims to uncover the problem of waqf and its solution at Pesantren Al-Falah Limboto Gorontalo. This research is field research, which is descriptive of analytical with the primer data and sekunder data. The data collection techniques used in this study are observation, interview, and documentation. While data analysis techniques include: data reduction, display, conclusions, and verification. The results showed that the procedure for the implementation of waqf at the Al-Falah Islamic Boarding School was originally carried out based on the principle of mutual trust without any element of doubt in the future it will cause problems. So that the agreement to hand over the donated land was not carried out. The path taken in resolving waqf disputes at the Al-Falah Islamic Boarding School is by deliberation or underhand. As for every heir who is deemed less capable of receiving mercy from the boarding school.
\end{abstract}

Keywords: Problems, Waqf, Settlement, Al-Falah Islamic Boarding School

\section{Waqf Problems and their Solutions in Pesantren Al-Falah, Limboto Barat, Gorontalo District}

\begin{abstract}
Abstrak: Penelitian ini bertujuan untuk menyibak problematika wakaf dan penyelesaiannya di Pesantren Al-Falah Limboto Gorontalo. Penelitian ini merupakan penelitian lapangan yang bersifat deskriptif analistis dengan data berupa data primer dan data sekunder. Teknik pengumpulan data yang digunakan dalam penelitian ini adalah pengamatan, wawancara, dan dokumentasi. Sedangkan teknik analisis data meliputi reduksi data, pemaparan, pengambilan kesimpulan, dan verifikasi. Hasil penelitian menunjukan bahwa prosedur pelaksanaan wakaf di Pondok Pesantren AlFalah pada mulanya dilakukan berdasarkan pada prinsip saling percaya tanpa ada unsur keraguan, namun kemudian hari akan menimbulkan masalah, sehingga perjanjian serah terima tanah wakafpun tidak dilakukan. Jalan yang ditempuh dalam penyelesaian sengketa wakaf di Pondok Pesantren Al-Falah adalah dengan jalur musyawarah atau dibawah tangan. Adapun setiap ahli waris yang dianggap kurang mampu mendapatkan santunan kerahiman dari pihak pondok pesantren sebagai bentuk terima kasih pihak pondok pesantren kepada ahli waris.
\end{abstract}

Kata Kunci: Problematika, Wakaf, Penyelesaian, Pesantren Al-Falah 


\section{A. Pendahuluan}

Hukum Islam adalah bagian dari kesatuan gabungan dari wahyu Allah swt. dengan suasana kondisi masyarakat yang telah ada dimana pada saat wahyu tersebut diturunkan ${ }^{1}$. Misi hukum Islam sebagai at uran untuk mengimplementasikan nilai-nilai aqidah dan keimanan serta mengemban misi utama, yaitu menegakan keadilan dan mendistribusikannya untuk seluruh kalanganmasyarakat, baik dalam ruang lingkup keadilan ekonomi, hukum dan sosial. Menjadi salah satu pranata sosial atau institusi Islam yang memiliki nilai sosial ekonomi adalah lembaga perwakafan. Sebagai inti dari esensial ajaran tauhid, artinya segala sesuatu berujung pada kesadaran akan adanya eksistensi Allah swt., lahirnya instrumen dalam bentuk lembaga perwakafan merupakan bukti adanya keinginan untuk membuka tabir eksistensi perwujudan sosial yang berkeadilan dalam Islam.

Hukum Islam sebagai sebuah tatanan sistem dari hukum tentunya diyakini memiliki kebenaran yang universal. Keuniversalitasan itu tergambar pada daya adaptafitas yang melampaui batasan-batasan waktu dan tempat. Keaktualitasan hukum Islam beriringan dengan perkembangan peradaban dan kemajuan umat manusia, serta adanya perubahan dinamika zaman. Olehnya itu, hukum Islam hendaknya dipahami sebagai tata aturan dan tata nilai yang diprediksi akan menjadi sebuah solusi alternatif terhadap permasalahan kehidupan manusia di dunia ini. ${ }^{2}$

Sebagaimana perlu diketahui bersama bahwa dalam doktrin Islam dan prinsip yang berkaitan dengan kepemilikan harta menjelaskan bahwa tidak dibenarkan harta hanya dikuasasi oleh seorangan atau bahkan sekelompok orang saja, hal ini dikhawatirkan akan memantik munculnya persoalan eksploitasi kelompok si kaya kepada kelompok si miskin, yang kemudian akan dapat melahirkan ketimpangan dan gesekan sosial sekaligus berdampak pada berbagaimacam implikasi negatif yang tidak terbendung banyaknya.

Wakaf memiliki posisi yang potensial sebagai sumber pendapatan dan belanjaan dalam masyarakat muslim. Sasaran wakaf bukan hanya untuk faqir miskin

\footnotetext{
${ }^{1}$ M. Quraisy Shihab, Mukjizat Al-Qur'an (Cet. 2; Bandung: Mizan, 1997), 222.

${ }^{2}$ Rizal Darwis, "Pemikiran Ibnu Qayyim al-Jauziyah terhadap Paradigma Perubahan Hukum," Adzkiya: Jurnal Hukum dan Ekonomi Islam, Vol. 5, No. 1 (2017): 68.
} 
atau kaum dhu'afa, namun juga untuk kepentingan publik dan masyarakat luas. Misalnya saja, untuk kepentingan bidang pendidikan, yaitu dengan mewakafkan tanah atau bangunan untuk tempat belajar, maka dari wakaf tersebut akan lahir sebuah amal jariyah yang pahalanya mengalir dan tidak putus selama harta benda tersebut dipergunakan. ${ }^{3}$

Sejak awal mula kedatangan Islam, persoalan yang berkaitan dengan wakaf bagi masyarakat indonesia dilakukan atas dasar pehaman sebagian besar mayoritas dengan menggunakan adat kebiasaan setempat yang telah lama terbangun dan menggunakan literatur paham Syafi'iyyah yang memang menjadi madzhab terbesar di Indonesia. ${ }^{4}$ Metode perwakafan sebelum adanya regulasi peraturan perundangundagngan yang mengaturnya, masih menggunakan aturan-aturan lama yang terbangun dari pola kebiasaan keagamaan dan adat setempat, misalnya proses wakaf tanah yang hanya menggunakan lisan saja, bahkan hanya dengan modal dan dasar rasa saling percaya kepada seseorang atau suatu lembaga tertentu dengan tidak melalui proses admisnistratif yang rapi. hal ini kemungkinan bisa saja terjadi diakibatkan persepsi masyarakat ketika saat itu masih beranggapan bahwa wakaf merupakan suatu amal ibadah semata, juga harta yang bersumber dari wakaf adalah milik Allah semata, dan tentu saja dalam paradigma mereka berasumsi bahwa tidak ada seorangpun yang akan berani untuk mempersengketakannya atau menggugatnya.

Oleh karena itu, secara faktual di lapangan persoalan praktik wakaf dalam dimensi implementatif di kehidupan masyarakat ternyata belum secara utuh terlaksana dengan baik dari segi administrasi, ketertiban, dan efisiensi. Terbukti dengan banyaknya berbagai problematika sengketa harta benda wakaf yang tidak terpelihara dan berjalan sebagaimana semestinya, entah diakibatkan oleh penelantaran atau bahkan beralih ke tangan pihak ketiga yang didapatkan dengan cara melawan ketentuan peraturan perundang-undangan. Tidak heran bahwa keadaan yang semakin carut marut demikian diakibatkan oleh kelalaian dan ketidaksanggupan nadzir dalam

\footnotetext{
${ }^{3}$ Imam Abi Husain Muslim Ibnu al-Hajj Ibn Muslim Qusyairi, Al-jamiu Shahih Musamma Shahih Muslim (Beirut Lebanon: Dar al-Ma'rifah, t.th.), 63.

${ }^{4}$ Muhammad Abid al-Kabisi, Ahkam Al-Waqf fi Al-Syari'ah Al-Islamiyah, terj. Ahrul Sani Fathurraham dan Kuwais, Hukum Wakaf(Cet. 1; Depok: Iman Press, 2004), 14.
} 
mengembangkan dan mengelola wakaf. Tidak sampai disitu saja salah satu faktor pendukung terjadinya permasalahan tersebut adalah tumbuh suburnya sikap apatisme atau ketidakpedulian dalam memahami status harta benda wakaf yang lazimnya untuk dijaga dan dilindungi agar melahirkan kesejahteraan umum yang sesuai dengan maksud, fungsi, dan tujuan peruntukan wakaf.

Pendataan dan administrasi wakaf pun merupakan elemen yang sangat penting dalam perwakafan. Hal ini disebutkan dalam Pasal 17 Undang-Undang Nomor 41 Tahun 2004 tentang Wakaf. Ikrar wakaf ini wajib dituangkan dalam Akta Ikrar Wakaf untuk mencegah terjadinya sengketa tanah wakaf yang disebabkan tidak jelasnya status dan kedudukan tanahnya, baik antara wakif dengan nadzir ataupun antara keluarga wakif dengan umat Islam setempat dengan nadzirnya. Di samping itu untuk mencegah terjadinya sengketa dalam kasus dimana setelah wakif meninggal dunia, sebagian ahli warisnya menolak dan tidak mengakui bahwa benda yang dimaksud adalah benda wakaf. Akta Ikrar Wakaf memiliki arti yang sangat urgen, karena dengan adanya Akta Ikrar Wakaf, maka sistem perwakafan tersebut memiliki kekuatan hukum sekaligus sebagai buktiotentik dalam akta yang akan dapat dijadikan pegangan untuk melindungi dan menjamin kelestarian, kesinambungan, dan kelanggengan eksistensi wakaf, yang nantinya dapat digunakan sebaga persiapan dalammenghadapi berbagai persoalan kedepan. ${ }^{5}$

Apabila telah terjadi sengketa wakaf maka ada langkah dalam penyelesaiannya. Peraturan tentang penyelesaian sengketa wakaf ini telah tertuang pada Pasal 62 Undang-Undang Nomor 41 Tahun 2004 tentang Wakaf. Dalam pasal tersebut menyebutkan bahwa penyelesaian sengketa perwakafan ditempuh melalui musyawarah untuk mufakat. Apabila penyelesaian sengketa melalui musyawarah tidak berhasil, sengketa dapat diselesaikan melalui mediasi, arbitrase, atau pengadilan. Musyawarah yang disebutkan di dalam pasal ini sesuai dengan apa yang ditetapkan oleh QS Ali

${ }^{5}$ Siti M. Mahamood, "Pembentukan Dana Wakaf Menurut Perspektif Syariah Dan UndangUndang Serta Aplikasinya di Malaysia," Jurnal Syariah, Vol. 15, No. 2 (2007): 61-83. 
Imran/3 ayat 158 yang menerangkan tentang anjuran untuk bermusyawarah dalam setiap urusan. ${ }^{6}$

Beberapa kasus terkait wakif dalam penyerahan harta wakafnya tidak melalui prosedur yang telah ditetapkan dalam aturan pemerintah yang ada sehingga walaupun secara syariat hukum Islamya sudah dianggap sah akan tetapi dalam tatanan sistem hukum positif Indonesia masih dianggap ilegal. Mengingat ada hak dibalik harta kepemilikan seseorang terhadap ahli warisnya maka hal ini akan sangat merugikan baik itu pada pihak wakif maupun nadzir di kemudian hari jika para ahli waris menuntut kembali terhadap harta wakif yang telah diwakafkan tersebut. Secara legal formal nadzir tidak memiliki bukti otentik mengenai keabsahan benda wakaf tersebut maka sudah dapat dipastikan wakaf menjadi batal. Hal ini disebabkan karena sebagian besar masyarakat memiliki pemahaman yang kuat bahwa wakaf adalah tindakan tabarru' (sukarela) yang tidak berharap imbalan. Dalam pelaksanaan wakafnya tidak mementingkan soal tertib administrasi, mulai dari Akta Ikrar Wakaf (AIW) sampai pensertifikatannya. Sebagian wakif merasa khawatir bahwa wakaf dengan tertib administrasi tersebut akan menimbulkan sifat pamer riya' dan mempengaruhi keikhlasan hatinya. ${ }^{7}$

Hal inilah dapat dipastikan bahwa sebagian wakif dalam penyerahan wakaf hanyalah memenuhi syarat sahnya wakaf menurut hukum Islam tanpa pembuatan Akta Ikrar Wakaf. Hal yang demikian ini, seperti yang terdapat di Pondok Pesantren AlFalah. Tanah di lingkungan Pondok Pesantren Al-Falah ini telah diwakafkan sejak tahun 1990. Para wakif yang berjumlah 5 orang merupakan saudara sekandung yang mempunyai niat tulus untuk mewakafkan harta warisan orang tuanya demi kepentingan pendirian pondok pesantren dan salah satu wakifnya berperan penting dalam pembangunan dan pengelolaan pondok pesantren, sehingga dengan secara langsung ia berperan sebagai wakif dan nadzir. Hal inilah yang kemudian menjadi sebuah problematika yang terjadi dalam status tanah wakaf yang dipermasalahkan oleh ahli waris.

\footnotetext{
${ }^{6}$ Nurhidayani, Muaidy Yasin, dan Busaini Busaini, "Pengelolaan Dan Pemanfaatan Wakaf Tanah dan Bangunan,” Maqdis: Jurnal Kajian Ekonomi Islam, Vol. 2, No. 2 (2017): 163-175.

${ }^{7}$ Akhmad Sirojudin Munir, "Optimalisasi Pemberdayaan Wakaf Secara Produktif," Ummul Qura, Vol. 6, No 2 (2018): 12-13.
} 
Oleh karena wakaf merupakan ibadah sosial dan pengurus merupakan wakif, maka segala sesuatu yang berkaitan dengan tanah wakaf tidak diadmistrasikan. Para wakif mewakafkan tanah wakaf ini dengan cara lisan dan atas dasar saling percaya terhadap nadzir. Mengingat, wakif yang berperan sebagai nadzir merupakan keluarga sekandung. Oleh karena dengan berkembang pesatnya pondok pesantren, maka kepengurusan wakaf menjadi kolektif. Tidak hanya pada pimpinan pondok dan jajarannya, melainkan kepada seluruh kepala-kepala madrasah di pesantren tersebut.

Pada tahun 2011, sebagian tanah wakaf disengketakan oleh sebagian ahli waris dikarenakan menganggap sebagian tanah tersebut bukanlah bagian dari tanah wakaf, apalagi ditambah dengan tidak adanya bukti otentik dari para nadzir. Tanah yang disengketakan ini merupakan tanah yang sudah berdiri di atasnya masjid dan beberapa asrama santri. Olehnya itu dengan dasar ini maka perlu dilakukan pengkajian terkait status tanah wakaf tersebut dan langkah-langkah atau solusi yang ditempuh dalam menyelesaikan kasus tanah wakaf yang terjadi di Pesantren Al-Falah.

\section{B. Wakaf sebagai Obyek Kajian Hukum Islam}

Pengertian wakaf atau waqf dari etimologi berasal dari bahasa Arab yaitu waqafa. Asal kata waqafa berarti menahan, berhenti, tetap berdiri. Kata waqafa - yaqifu - waqfan sama artinya dengan habasa - yahbisu - tahbisan. ${ }^{8}$ Kata al-waqf dalam bahasa Arab mengandung beberapa pengertian, yaitu: al-khayr (kebaikan), ${ }^{9}$ shadaqah jariyah, ${ }^{10}$ dan al-habs. ${ }^{11}$

\footnotetext{
${ }^{8}$ Muhammad al-Khatib, al-Iqna' (Bairut: Darul Ma“rifah, t.th.), 26. Lihat pula Wahbah Zuhaili, Al-Fiqhu al-Islami wa 'Adillatuhu (Damaskus: Dar al-Fikr al-Mu'ashir, t.th.), 7599.

${ }^{9}$ Taqiy al-Din Abi Bakr Ibn Muhammad al-Husaini al-Dimasqi, Kifayat al-Akhyar fi Hall Gayat al-Ikhtishar, Juz 1 (Semarang: Toha Putra, t.th), 319. Dalam tafsirannya bahwa perintah untuk melakukan al-khayr berarti perintah untuk melakukan wakaf.

${ }^{10}$ Imam Abi Husain Muslim bin Hajjaz, Shahih Muslim, Juz 3 (Bairut: Darul Kitab al-Alamiyyah, t.th.), 1255. Hadis terkait put usnya amal manusia ketika meninggal kecuali 3 hal, yaitu sadaqah jariyah, ilmu yang bermanfaat dan doa anak saleh. Imam Muslim menjelaskan bahwa wakaf disebut dengan sadaqah jariyah. Wakaf dalam perspektif ini dianggap sebagai bagian dari sedekah. Secara umum, sedekah dapat dibedakan menjadi dua, yaitu: sedekah yang wajib dan sedekah yang sunah. Sedekah wajib yaitu zakat, sedangkan sedekah yang sunnah ada dua macam pula, yaitu: sedekah yang pahalanya tidak senantiasa mengalir, dan sedekah yang pahalanya senantiasa mengalir meskipun pihak yang menyedekahkan hartanya telah meninggal dunia. Sedekah yang terakhir disebut wakaf.

${ }^{11}$ Muhammad Ibn Idris al-Syafi'i, Al-Umm, Juz 3 (Mesir: Maktabah Kuliyah al-Azhariyah, t.th.), 51. Imam Syafi'i dalam al-Umm memberikan nomenklatur wakaf dengan al-ahbas.
} 
Secara terminologi pengertian wakaf berbeda antara satu ulama dengan ulama lainnya, antara lain: Mazhab Hanafiyah berpendapat wakaf adalah tertahannya suatu benda yang menurut hukum masih tetap kepemilikannya oleh si wakif untuk dipergunakan kemanfaatannya dalam kebajikan. Ini berarti kepemilikan harta/benda wakaf tidak lepas dari si wakif, bahkan dibenarkan si wakif untuk menariknya kembali dan menjualnya boleh. Jika si wakif telah meninggal dunia, maka harta wakaf itu menjadi harta warisan bagi ahli warisnya. Kesimpulannya wakaf ini hanyalah menyumbangkan manfaatnya saja. ${ }^{12}$

Mazhab Maliki berpendapat bahwa wakaf tidak melepaskan harta yang diwakafkan dari kepemilikan wakif, namun wakif wakaf tersebut mencegah wakif melakukan tindakan yang dapat melepaskan kepemilikannya atas harta tersebut kepada yang lain dan wakif berkewajiban menyedekahkan manfaatnya serta tidak boleh menarik kembali wakafnya. ${ }^{13}$ Mazhab Syafi'i berpendapat bahwa wakaf adalah melepaskan harta yang diwakafkan dari kepemilikan wakif, setelah sempurna prosedur perwakafan. Wakif tidak boleh melakukan apa saja terhadap harta yang diwakafkan, seperti : perlakuan pemilik dengan cara pemilikannya kepada yang lain, baik dengan tukaran atau tidak. Jika wakif wafat, harta yang diwakafkan tersebut tidak dapat diwarisi oleh ahli warisnya. Oleh karena harta yang sudah diwakafkan sudah menjadi milik Allah swt. dengan menyedekahkan manfaatnya kepada suatu kebajikan. ${ }^{14}$

Mazhab Hanabilah berpendapat bahwa wakaf adalah menahan pokok dan menyalurkan hasilnya pada kebajikan. ${ }^{15}$ Selanjutnya defenisi lebih lengkap dinyatakan oleh Musa bin Ahmad al-Hajjadi bahwa wakaf adalah tindakan orang dewasa yang cakap bertindak menurut hukum untuk menahan harta yang dapat diambil manfaatnya dan memiliki karakter lestari dengan memutuskan berbagai transaksi serta menyalurkan pada sektor-sektor kebajikan dengan tujuan mendekatkan diri kepada Allah swt. ${ }^{16}$

\footnotetext{
${ }^{12}$ Ibn al-Humam al-Hanafi, Syarah Fath al-Qadir, Jilid 6 (Bairut : Darr al-Kutub al-Ilmiyah, 1995), 190.

${ }^{13}$ Malik bin Anas, Al-Mudawwanah al-Kubra, Juz 4 (Bairut: Dar al-Kutub al-Ilmiyah, t.th), 417.

${ }^{14}$ Abu Zakaria Muhyiddin Yahya bin Sharaf an-Nawawi, Kitab al-Majmu al-Muhadzdzab, Juz 16 (t.tp: Dar Ihya al-Turats al-Arabi, 1995), 243.

${ }^{15}$ Ibnu Qudamah, Al-Mughni, Juz 5 (Riyadh : Maktabah al-Riyadh al-Haditsiyah, 1941), 567.

${ }^{16}$ Mansyur bin Yunus bin Idris al Bahuti, Kasysyafa al-Qina' an Matn al-Iqnā (Bairut: Dar alKutub al-Ilmiyah, t.th), 293.
} 
Mazhab Imamiyah berpendapat sama dengan mazhab ketiga, namun berbeda dari segi kepemilikan atas benda yang diwakafkan, yaitu menjadi milik mauquf 'alaih (yang diberi wakaf), meskipun mauquf 'alaih tidak berhak melakukan sesuatu tindakan atas benda wakaf tersebut, baik menjual atau menghibahkannya. ${ }^{17}$

Berdasarkan beberapa pengertian dari etimologi dan terminologi, maka diketahui adanya perbedaan baik dari segi kepemilikan harta wakaf, hakikat wakaf, aspek kontinyuitas waktu, zat yang diwakafkan, pola pemberdayaan dan pemanfaatan harta wakaf itu sendiri.

Wakaf sebagai salah satu bentuk ibadah kepada Allah swt. didasarkan pada firman Allah swt dalam Alquran, yaitu:

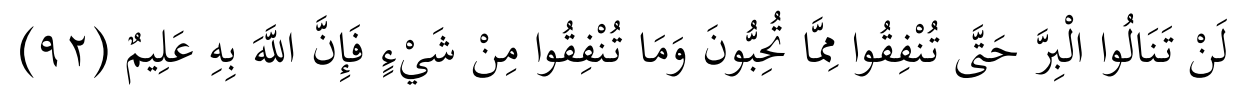

Terjemahnya:

Kamu tidak akan memperoleh kebajikan, sebelum kamu menginfakkan sebagian harta yang kamu cintai. Dan apa pun yang kamu infakkan, tentang hal itu. Sungguh Allah Maha Mengetahui (QS Ali Imran/3: 92). ${ }^{18}$

Begitu pula ditegaskan dalam hadis Rasulullah saw., yaitu:

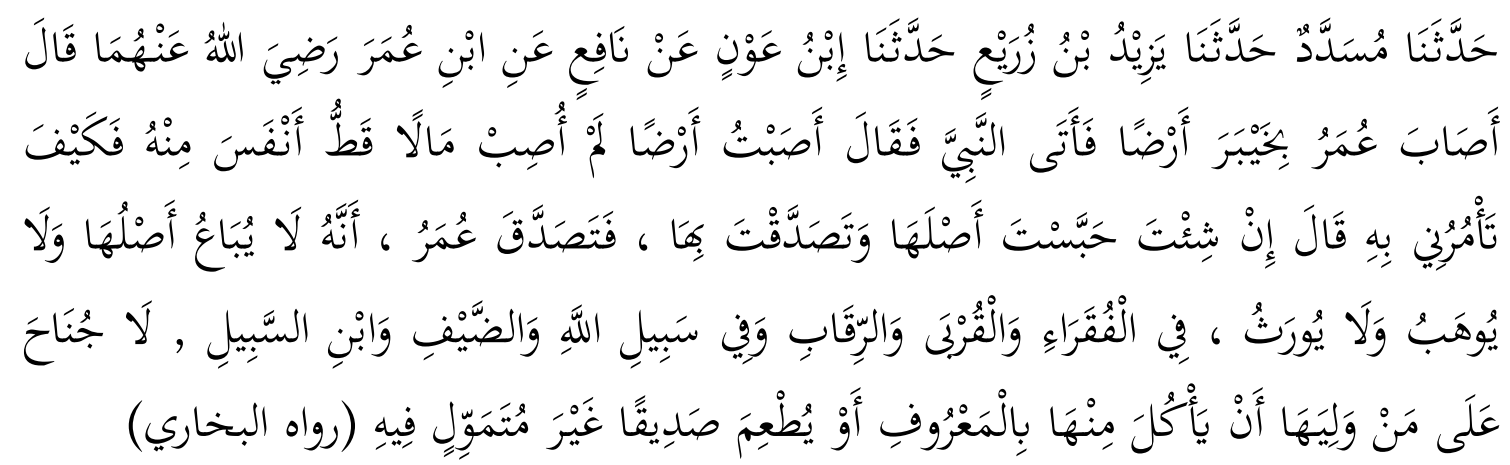

Artinya:

Telah menceritakan kepadaku Musaddad dari Yazid bin Zurai, dari Ibn Aun dari Nafi' dari Ibnu Umar ra., beliau berkata bahwa Umar memiliki tanah khaibar, kemudian datang Rasulullah saw. lalu Umar bertanya kepada beliau, saya memiliki sebidang tanah yang tidak saya ambil sama sekali dari bumi tersebut, bagaimana menurut engkau? bersabda: ketika manusia meninggal, maka terputuslah amalnya kecuali dari tiga perkara, yaitu shadaqah jariyah, ilmu yang bermanfaat, atau anak shaleh yang mendoakannya. Lalu Nabi saw. bersabda: jika engkau menghendaki, jagalah dan shodakohkan. Maka Umar mensedekahkannya dan sesungguhnya tidak

\footnotetext{
${ }^{17}$ Wahbah Zuhaili, Al-Fiqhu al-Islami wa 'Adillatuhu, 7599.

${ }^{18}$ Kementerian Agama RI., Ummum Mukminin: Al-Qur'an dan Terjemahan untuk Wanita (Ciputat: Penerbit Wali, 2010), 62.
} 
dijual aslinya, tidak dihibahkan, dan tidak diwariskan pada orang-orang fakir, kerabat, riqaab (untuk memerdekakan hamba sahaya), sabilillah (jalan Allah), tamu, ibnu sabil (orang yang dalam perjalanan) dan kerabat. Dan tidak ada dosa bagi orang yang mengurusinya untuk memakan secara baik atau memberi makan temannya dengan tidak mengambil alih harta itu. ${ }^{19}$

Selain kedua dalil tersebut, perwakafan juga diatur dalam perundang-undangan nasional di Indonesia, yaitu Undang-Undang Nomor 41 Tahun 2004 tentang Wakaf:

Wakaf adalah perbuatan hukum wakif untuk memisahkan dan/atau menyerahkan sebagian harta benda miliknya untuk dimanfaatkan selamanya atau untuk jangka waktu tertentu sesuai dengan kepentingannya guna keperluan ibadah dan/atau kesejahteraan umum menurut syariah. ${ }^{20}$

Berdasarkan ketiga dasar hukum tersebut, maka diketahui bahwa eksistensi wakaf sangat jelas diatur, baik dari hukum Islam maupun hukum nasional di Indonesia, sehingga hal ini menjadi sebuah aturan dalam pelaksanaan sistem perwakafan di Indonesia. Pelaksanaan dari wakaf juga tidak bisa dilepaskan dari pihak-pihak yang melaksanakan wakaf tersebut, sehingga sah berdasarkan hukum. Unsur-unsur wakaf itu dapat dilihat dari terpenuhinya rukun dan syarat wakaf. Adapun rukun wakaf itu terdiri dari wakif, mauquf bih, mauquf alaih, dan shigat. ${ }^{21}$

1. Wakif (orang yang mewakafkan hartanya)

Wakif hendaknya memiliki syarat-syarat sebagai berikut:

a. Merdeka; wakaf yang dilakukan oleh seorang budak (hamba sahaya) tidak sah, karena wakaf adalah pengguguran hak milik dengan cara memberikan hak milik itu kepada orang lain. Sedangkan hamba sahaya tidak mempunyai hak milik, dirinya dan apa yang dimiliki adalah kepunyaan tuannya. ${ }^{22}$

b. Berakal sehat; wakaf yang dilakukan oleh orang gila atau lemah mental (idiot) tidak sah hukumnya, sebab ia tidak berakal sempurna, tidak mumayyiz dan tidak cakap melakukan akad serta tindakan lainnya. ${ }^{23}$

\footnotetext{
${ }^{19}$ Abū 'Abd Allāh Muhạmmad ibn Ismā'îl ibn Ibrāhīm ibn al-Mughīrah ibn Bardizbah al-Ju'fī alBukhārī, Sạīh Bukhārī, No. Hadis 2565 (Beirut: Dar al- Fikr, 1981), 259.

${ }^{20}$ Republik Indonesia, Undang-Undang Nomor 41 Tahun 2004 tentang Wakaf, Pasal 1, Angka 1.

${ }^{21}$ Al-Imam Muhyiddin Abu Zakariya bin Syaraf an-Nawawi ad-Dimasyqi, Ar-Raudhah, Juz 2 (Bairut: Dar al-Kutub al-Ilmiah, t.th.), 377.

${ }^{22}$ Syaikh Ibrahim al-Baijuri, Hasyiyah al-Baijuri, Juz 2 (Bairut: Dar al-Fikr, t.th.), 44.

${ }^{23}$ Al-Imam Syamsuddin Muhammad bin Muhammad al-Khathib asy-Syarbini, Mughni al-Muhtaj (Kairo: Mushthafa Habibi, t.th), 377.
} 
c. Dewasa (baligh); wakaf yang dilakukan oleh anak yang belum baligh, hukumnya tidak sah karena dipandang tidak cakap melakukan akad dan tidak cakap pula untuk menggugurkan hak miliknya. ${ }^{24}$

d. Tidak berada di bawah pengampuan (boros/lalai); orang yang berada di bawah pengampuan dipandang tidak cakap untuk berbuat kebaikan (tabarru'), maka wakaf yang dilakukan hukumnya tidak sah. ${ }^{25}$

2. Mauquf bih (barang atau harta yang diwakafkan)

Barang atau harta wakaf terbagi menjadi dua syarat, yaitu:

a. Syarat sahnya harta wakaf; harta yang akan diwakafkan harus memenuhi lima syarat: (1) harta mutaqawwam, yaitu segala sesuatu yang dapat disimpan dan halal digunakan dalam keadaan normal (bukan dalam keadaan darurat); (2) diketahui dengan yakin ( 'ainul ma'lumun), sehingga tidak akan menimbulkan persengketaan; (3) milik wakif, yaitu harta yang akan diwakafkan adalah milik penuh dan mengikat bagi wakif ketika ia mewakafkan; (4) terpisah, bukan milik bersama (musya'); dan (5) syarat-syarat yang ditetapkan wakif (terkait harta wakaf), yaitu syarat-syarat yang ditetapkan wakif dalam ikrar wakafnya itu atas kemauan sendiri,bukan dalam keadaan paksaan. ${ }^{26}$

b. Kadar harta yang diwakafkan; konsep pembatasan harta yang ingin diwakafkan oleh wakif dalam fikih tidak ada, dengan pengertian lain bahwa harta yang akan diwakafkan seseorang tidak dibatasi dalam jumlah tertentu sebagai upaya menghargai keinginan wakif. Orang yang mewakafkan hartanya (wakif) lebih dari sepertiga hartanya, maka tetap sah wakaf tersebut walaupun ahli warisnya menolak terhadap harta yang akan diwakafkan lebih dari sepertiga. ${ }^{27}$

3. Mauquf 'alaih (pihak yang diberi wakaf atau peruntukan wakaf)

Syaratnya dalam pengelolaan harta wakaf, mauquf'alaih harus memenuhi syarat adil dan mengerti atau mampu. ${ }^{28}$ Para Imam mazhab sepakat pentingnya mauquf 'alaih

\footnotetext{
${ }^{24}$ Ibid.

${ }^{25}$ Syaikh Ibrahim al-Baijuri, Hasyiyah al-Baijuri, Juz 2, 45.

${ }^{26}$ Imam asy-Syarbini, Mughni al-Muhtaj, 377.

${ }^{27}$ Zainuddin al-Malibari, Fathul Mu'in (Surabaya : Al-Haromain Jaya Indonesia, t.th.), 88.

${ }^{28}$ Ibid., h. 91.
} 
atau nazhir memenuhi syarat adil dan mampu atau mengerti. Menurut jumhur ulama maksud adil adalah mengerjakan yang diperintahkan dan menjahui segala yang dilarang oleh syariat Islam. Sedangkan maksud mampu ialah kekuatan dan kemampuan atau pengetahuan seseorang men-tasharruf-kan apa yang dijaga (dikelolanya).

\section{Shighat (pernyataan atau ikrar wakif)}

Shighat wakaf ialah segala ucapan atau tulisan isyarat dari orang yang berakad untuk menyatakan kehendak dan menjelaskan apa yang diinginkannya. Adapun syaratsyarat shighat sebagai berikut :

a. Shighat harus munjazah (terjadi seketika/selesai). Maksudnya ialah shighat tersebut menunjukkan terjadi dan terlaksananya wakaf seketika setelah shighat ijab diucapkan atau ditulis, misalnya berkata: saya mewakafkan tanah saya atau saya sedekahkan tanah saya sebagai wakaf.

b. Shighat tidak diikuti syarat batil (palsu). Maksudnya ialah syarat yang menodai atau mencederai dasar wakaf atau meniadakan hukumnya, yakni kelaziman dan keabadian. Misalnya wakif berkata: saya wakafkan rumah ini untuk diri saya sendiri seumur hidup, kemudian setelah saya meninggal untuk anak-anak dan cucucucu saya dengan syarat bahwa saya boleh menjual atau menggadaikannya kapan saja saya kehendaki.

c. Shighat tidak diikuti pembatasan waktu tertentu (wakaf tersebut tidak untuk selamanya). Wakaf adalah shadaqah yang disyariatkan untuk selamanya.

d. Tidak mengandung suatu pengertian untuk mencabut kembali wakaf yang sudah dilakukan. $^{29}$

Wakaf sebagai obyek kajian dalam hukum Islam memiliki dasar hukum dalam pelaksanaannya, baik itu berdasarkan Alquran, hadis Nabi saw., maupun produk hukum Islam di Indonesia sebagai bagian hukum nasional yang mandiri. Selain itu juga dalam proses pelaksanaannya tetap memperhatikan sah atau tidaknya proses wakaf itu dengan mencermati rukun dan syarat-syarat wakaf tersebut.

\footnotetext{
${ }^{29}$ Departemen Agama, Fiqih Wakaf (Jakarta: Proyek Peningkatan Pemberdayaan Wakaf, Direktorat Jenderal Bimbingan Masyarakat Islam dan Penyelenggara Haji, 2004), 57.
} 


\section{Pelaksanaan Wakaf di Pondok Pesantren Al-Falah}

Pondok Pesantren Al-Falah terletak di Jalan Ki Hajar Dewantara Desa Tunggulo Kecamatan Limboto Barat Kabupaten Gorontalo. Berdiri pada tahun 1990 atas Yayasan Hamrain Kau. Pondok pesantren ini berdiri di atas tanah wakaf dengan luas tanah $50.000 \mathrm{~m}^{2}$. Dengan berkembangnya Pondok Pesantren Al-Falah, saat ini luas Pondok Pesantren ini telah mencapai $70.000 \mathrm{~m}^{2}$ atau $7 \mathrm{Ha}$. Para wakif berjumlah 5 orang merupakan saudara sekandung yang mempunyai niat tulus untuk mewakafkan harta warisan orang tuanya demi kepentingan pendirian pondok pesantren. Mereka mewakafkan tanah seluas $5.000 \mathrm{~m}^{2}$ yang dipisahkan lebih dulu sebelum pembagian harta warisan orang tua mereka. $45.000 \mathrm{~m}^{2}$ lainnya diwakafkan oleh Hamrain Kau selaku pimpinan sekaligus pendiri Pondok Pesantren Al-Falah, sebagian lainnya dibeli dengan uang dari para donatur. Pondok Pesantren Al-Falah bergerak di bidang pendidikan berbasis madrasah, terdiri atas Madrasah Aliyah, Madrasah Tsanawiyah, Madrasah Ibtidaiyah, Progam Paket A, B, dan C.

Adapun visi, misi, tujuan, dan sasaran Pondok Pesantren Al-Falah, yaitu:

1. Visi untuk mewujudkan madrasah yang beriman dan bertaqwa, berprestasi, bertanggung jawab dan memiliki wawasan keilmuwan dan kearifan.

2. Misi untuk melaksanakan peningkatan mutu pelajaran pembelajaran, menciptakan proses belajar yang efektif dan efesien, menanamkan minat baca pada warga Pondok Pesantren sebagai kebutuhan iptek dan imtaq, meningkatkan kwalitas pembelajaran anak didik, menumbuhkan kerjasama yang nyata diantara seluruh komponen yang peduli pada pendidikan, menyediakan wahana pembinaan pengembangan bakat pada bidang keterampilan,olahraga dan seni, melaksanakan pembinaan kerohanian secara kontinyu bagi warga Pondok Pesantren.

3. Tujuan untuk menjadikan siswa berprestasi di bidang akademik maupun non akademik

4. Sasaran adalah peningkatan kwalitas sumberdaya manusia dan perlengkapan sarana dan prasarana penunjang. ${ }^{30}$

\footnotetext{
${ }^{30}$ Sumber data dari Pondok Pesantren Al-Falah Tunggulo Limboto Barat Gorontalo.
} 
Pondok Pesantren Al-Falah sebagai pusat pendidikan yang berbasis madrasah, terletak di daerah yang sangat strategis dan nyaman dalam menuntut ilmu pada tingkatan yang diprogramkan. Dengan letak wilayah yang berada pada titik pusat lingkungan yang sangat agamis, sehingga sangat memungkinkan Al-Falah terus berbenah sebagai pusat pendidikan pesantren yang berada di Kabupaten Gorontalo.

Wakaf merupakan salah satu lembaga hukum yang berasal dari hukum Islam yang dilakukan dalam rangka melaksanakan ibadah kepada Allah, dan dalam tataran pelaksanaannya wakaf lazim memenuhi rukun dan syaratnya wakaf. Rukun wakaf ada empat yaitu adanya wakif, harta yang akan diwakafkan, tempat dimana benda akan diwakafkan dan akad. Benda wakaf berdasarkan hukum Islam meliputi semua harta yang dimiliki oleh wakif. Pelaksanaan wakaf di Indonesia seperti dijelaskan pada bab sebelumnya didasarkan pada paham keagamaan yang dianut, yaitu faham Syafi'iyyah dan adat kebiasaan setempat. Sebelum adanya Undang-Undang Nomor 5 Tahun 1960 tentang Peraturan Dasar Pokok Agraria dan Peraturan Pemerintah Nomor 28 Tahun 1977 tentang Perwakafan Tanah Milik, sebagian besar masyarakat Islam di Indonesia masih memakai kebiasaaan-kebiasaaan dari keagamaan, atau tradisi seperti kebisaaan untuk melakukan tindakan hukum perwakafan tanah dengan cara lisan atas dasar saling berpegang percaya kepada seorang/individu atau suatu lembaga tertentu, kebiasaan melihat wakaf sebagai suatu amal sholeh yang memiliki nilai kemuliaan dan keagungan di hadapan Allah tanpa harus melalui tatacara dan prosedur administratif, dan harta wakaf diasumsikan milik Allah semata, dimana siapa saja tidak akan berani mengganggu gugat. ${ }^{31}$

Selain tradisi lisan yang telah lama mendarah daging dan besarnya animo dan harapan kepercayaan kepada sang penerima amanah di dalam melakukan wakaf, masyarakat muslim Indonesia banyak mengambil pendapat-pendapat dari golongan Syafi'iyyah sebagaimana mereka yang mengikuti dan mempraktekan mazhabnya, misalnya pada persoalan tentang: ikrar wakaf, harta apa saja yang boleh untuk diwakafkan, kedudukan dan status harta setelah diwakafkan, harta wakaf yang dituju

\footnotetext{
${ }^{31}$ Mohamad A. Laldin, Mek Wok Mahmud, And Mohd Fuad Sawari, "Maqasid Syariah Dalam Pelaksanaan Waqaf," Jurnal Pengurusan Jawhar, Vol. 2, No. 2 (2008): 1-24.
} 
maksudkan kepada siapa dan kebolehan atau tidaknya melakukan tukar menukar harta wakaf.

Secara implementatif prosedural pelaksanaan wakaf bagi seorang wakif sangatlah mudah dan sederhana, dimana si wakif terlebih dahulu melaksanakan akad wakaf kepada nadzir yang disaksikan minimal oleh 2 orang saksi yang dianggap adil. Akad wakaf itu dapat dilaksanakan cukup hanya dengan secara lisan. Apabila wakaf telah selesai dilakukan dengan benar serta memenuhi ketentuan rukun dan syaratnya, maka wakaf telah dianggap sah secara hukum Islam. Akibat hukumnya benda wakaf akan beralih fungsinya untuk segala kepentingan umat dan Allah swt.atau untuk ibadah. Sedangkan jenis hartanya tidak dibatasi, sehingga apapun harta yang dipunyai oleh wakif secara keseluruhan dapat diwakafkan. ${ }^{32}$

Sementara menurut hukum positif Indonesia, prosedur dalam pelaksanaan wakaf tidak cukup akad wakaf dilakukan secara lisan saja. Untuk menjamin kepastian hukum Undang-Undang Nomor 41 Tahun 2004 mengharuskan wakaf dilakukan secara lisan dan tertulis di hadapan Pejabat Pembuat Akta Ikrar Wakaf (PPAIW) untuk selanjutnya dibuat Akta Ikrar Wakaf (AIW). Atas dasar AIW, maka tanah hak milik yang diajukan perubahannya ke Badan Pertanahan Nasional setelah dianggap memenuhi syarat administrasinya untuk dapat diubah menjadi sertifikat wakaf. Walaupun pada kenyataan yang ada di masyarakat, dapat ditemukan tanah wakaf yang belum mendapatkan sertifikat wakaf, meskipun akta ikrar wakaf telah diterima. ${ }^{33}$

Prosedur pelaksanaan wakaf di Pondok Pesantren Al-Falah dilaksanakan dengan berdasarkan ajaran agama Islam, yaitu hanya memenuhi syarat sahnya wakaf dalam hukum agama tanpa memperhatikan pengadministrasiannya, di mana di lingkungan Pondok Pesantren Al-Falah ini telah diwakafkan sejak tahun 1990. Para wakif yang berjumlah 5 orang merupakan saudara sekandung, di mana mereka mempunyai niat tulus untuk mewakafkan harta warisan orang tuanya demi kepentingan pendirian pondok pesantren. Adapun salah satu wakif berperan penting dalam pembangunan dan

\footnotetext{
${ }^{32}$ Slamet Santoso, Rancangan Penelitian, Metodologi Penelitian Biomedis, Edisi 2, (Jakarta: Surya Medina, 2008), 33.

${ }^{33}$ Nur Fadhilah, "Sengketa Tanah Wakaf Dan Strategi Penyelesaiannya," De Jure: Jurnal Hukum dan Syar'iah, Vol. 3, No. 1 (2011); 42.
} 
pengelolaan pondok pesantren, sehingga, dengan secara langsung ia berperan sebagai wakif dan nadzir.

Menurut Sumarni Ohi bahwa pada awalnya tanah wakaf di Pondok Pesantren AlFalah berkisar seluas 5 hektar berasal dari keluarga Kau, dan sampai dengan saat ini areal tanah untuk Pondok Pesantren Al-Falah kurang lebih berkisar 7 ha. Sisa lebih dari total luas tanah yang ada untuk areal Pondok Pesantren Al-Falah dibeli dari sumbangan para dermawan. Tanah seluas itu sebagian besarnya telah dijadikan sebagai lokasi pembangunan fasilitas pendidikan Pondok Pesantren Al-Falah seperti ruang belajar, asrama putra dan asrama putri, masjid, perpustakaan, lapangan olahraga, dan bangunan lainnya. $^{34}$

Menurut pengasuh Pondok Pesantren Al-Falah bahwa pada awalnya Pondok Pesantaren Al-Falah didirikan olah Hamrain Kau, dimana beliau ini merupakan anak ke 2 dari 5 orang bersaudara yang merupakan wakif tanah pada Pondok Pesantren AlFalah, di mana dari kelima bersaudara tersebut, Hamrain Kau merupakan sosok yang lebih unggul dalam hal baik pendidikan maupun wawasan khasanah keislamannya. Mengingat beliau sempat menimbah pendidikan di pondok pesantren terbesar di Jawa Timur, maka selepas menyelesaikan pendidikan di pondok pesantren tersebut Hamrain Kau berinisiatif untuk mendirikan pondok pesantren di kampung halaman guna kepentingan dakwah Islamiyah. ${ }^{35}$

Sejalan dengan itu, berdasarkan penuturan Zainul Romiz Koesry selaku Pimpinan Pondok Pesantren Al-Falah bahwa pada awalnya tanah wakaf yang ada di Al-Falah merupakan tanah milik orang tua dari lima bersaudara si wakif. Kemudian sudah menjadi bagian dari masing-masing ahli waris berdasarkan penetapan dan pembagian sebagaimana hukum Islam yang berlaku. Hingga pada suatu saat lahirlah inisiatif Hamrain Kau yang hendak mendirikan pondok pesantren di area tanah hasil pembagian warisan orang tuanya yang kebetulan masih satu area dengan sebagian tanah pembagian hasil warisan milik saudara-saudaranya. Dari inisiatif inilah kemudian di dukung oleh saudara-saudaranya dengan menyerahkan sebagian harta kepemilikan

\footnotetext{
${ }^{34}$ Sumarni Ohi, Kepala Madrasah Aliyah, Wawancara di Madrasah Aliyah Al-Falah, tanggal 23 Juni 2012.

${ }^{35}$ Mohammad Juwaini, Pengasuh Pondok Pesantren Al-Falah, Wawancara, di Pondok Pesantren Al-Falah, tanggal 23 Juni 2012.
} 
berupa tanah yakni seluas $5000 \mathrm{~m}^{2}$ untuk selanjutnya dijadikan sebagai lahan untuk mendirikan lokasi pondok pesantren hingga saat ini. Dalam artian, para wakif menyisihkan sebagian tanah yakni seluas $5.000 \mathrm{~m}^{2}$ untuk diwakafkan sebelum membagi harta warisan mereka. Para wakif mewakafkan tanah wakaf ini dengan cara lisan dan atas dasar saling percaya terhadap nadzir. Mengingat, wakif yang berperan sebagai nadzir merupakan keluarga sekandung. ${ }^{36}$

Sampai pada suatu saat silih berganti generasi, penyerahan harta wakaf ini dipermasalahkan oleh sebagian anak-anak si wakif yang tidak lain keluarga sendiri karena anak-anak si wakif beranggapan bahwa lahan yang telah digunakan sebagai lokasi pembangunan itu bukanlah harta wakaf yang telah diserah terimakan olah para pendahulunya yakni orang tua. Berdasarkan data informan sebagaimana yang telah di uraikan di atas, maka pada pelaksanaannya bahwa prosedur wakaf yang ada di lingkungan Pondok Pesantren Al-Falah merupakan bentuk wakaf yang lahir karena adanya hubungan kekeluargaan (wakaf li ahlihi) dalam rangka pendirian sarana dan prasarana pendidikan untuk kepentingan syiar Islam yang dalam penyerahanya cukup dengan akad lisan sebagaimana halnya Islam mengatur dan tidak tertulis secara resmi oleh badan yang berwenang. Sehingga, pelaksanaan wakaf di sini berdasarkan ajaran Islam dengan memenuhi rukun dan syarat sahnya wakaf.

\section{Upaya-Upaya Penyelesaian Sengketa Wakaf Bawah Tangan di Pondok Pesantren Al-Falah}

Sebuah konflik yakni sebuah situasi dimana terdapat antara dua pihak atau lebih yang diperhadapkan dengan perbedaan unsur kepentingan, pada hakikatnya perihal yang dimaksudkan tidak akan berubah menjadi sebuah problmetika atau sengketa bilamana salah satu diantara kedua belah pihak tidak ada yang merasa dirugikan. ${ }^{37}$ Ini diartikan bahwa sengketa adalah proses dari kelanjutan setelah adanya konflik, dan konflik kapanpun dapat bertranformasi menjadi sebuah sengketa berkepanjangan

\footnotetext{
${ }^{36}$ Zainul Romiz Keosry, Pimpinan Pondok Pesantren Al-Falah, Wawancara di Pondok Pesantren Al-Falah, tanggal 29 Juni 2012.

${ }^{37}$ Siti Megadianti Adam dan Takdir Rahmadi, Sengketa Dan Penyelesainya' Buletin Musyawarah Nomor 1 (Jakarta: Indonesia Center For Law, 1997) dalam Rahmadi Usman, Pilihan Penyelesaian Sengketa Diluar Pengadilan (Bandung: Citra Aditya Bakti, 2003), 1.
} 
bilamana tidak segera diselesaikan, maka sepanjang persoalan tersebut dapat diselesaikan oleh kedua belah pihak yang bersangkutan, sengketa yang dimaksud tidak akan terjadi.

Secara umum pola penyelesaian sengketa dilakukan dengan menggunakan dua pola, yaitu: Pertama, melalui litigasi yaitu penyelesaian sesuai prosedur dan mekanisme formal peradilan di pengadilan, yang biasanya memakan banyak biaya dan waktu serta berbagai macam implikasi yang dilahirkannya; dan Kedua, melalui jalur non litigasi yaiu penyelesaian sengketa lewat jalur luar pengadilan atau non formalis, biasanya disebut dengan mediasi, arbitrase dan lainnya. Metode ini senantiasa mengedepankan prinsip win-win solution, guna mencari jala tengah agar tidak ada diantara kedua belah pihak yang bersengketa merasa dirugikan dan metode ini sangat meminimalisir biaya dan waktu, tanpa harus terpenjara oleh rumitnya prosedural administratif sebagaimana yang terjadi pada metode litigasi umumnya.

Pasal 62 Undang-Undang Nomor 41 Tahun 2004 tentang Wakaf juga menjelaskan bahwa secara aplikatif penyelesaian sengketa perwakafan dapat dilakukan melalui musyawarah untuk mufakat. Apabila tahapan penyelesaian sengketa melalui musyawarah gagal atau tidak berhasil, sengketa dapat diselesaikan melalui metode mediasi, arbitrase, atau peradilan di pengadilan. Kemudian disebutkan didalam penjelasannya, bahwa yang dimaksudkan dengan mediasi yaitu penyelesaian sengketa dengan menggunakan bantuan pihak ketiga (mediator) yang disepakati oleh pihak yang berperkara atau bersengketa. Dalam hal mediasi jika tidak berhasil menyelesaikan sengketa, maka sengketa dapat dilanjutkan dan dibawa kepada badan arbitrase syariah. Jika badan arbitrase syariah tidak berhasil menyelesaikan sengketa, maka sengketa perwakafan tersebut dapat dibawa ke ranah Pengadilan Agama dan/atau Mahkamah Syariah. $^{38}$

Persengketaan disebabkan oleh beberapa faktor yang melatarbelakanginya, sehingga langkah penyelesaian dalam persengketaan juga harus memperhatikan sebab terjadinya sengketa, yaitu:

${ }^{38}$ Wawan Hermawan, "Politik Hukum Wakaf di Indonesia," Jurnal Pendidikan Agama IslamTa'lim, Vol. 12, No. 2 (2014): 147-161. 
a. Sebab Terjadinya Sengketa

Hal pokok yang sering menimbulkan permasalahan perwakafan dalam praktik adalah masih banyaknya wakaf tanah yang tidak ditindaklanjuti dengan pembuatan akta ikrar wakaf. Pelaksanaan wakaf yang terjadi di Indonesia masih banyak yang dilakukan secara agamis atau mendasarkan pada rasa saling percaya. Kondisi ini pada akhirnya menjadikan tanah yang diwakafkan tidak memiliki dasar hukum, sehingga apabila dikemudian hari terjadi permasalahan mengenai kepemilikan tanah wakaf penyelesaiannya akan menemui kesulitan, khususnya dalam hal pembuktian. Hal lain yang sering menimbulkan permasalahan dalam praktik wakaf di Indonesia adalah dimintanya kembali tanah wakaf oleh ahli waris wakif dan tanah wakaf dikuasai secara turun temurun oleh Nadzir yang penggunaannya menyimpang dari akad wakaf.

Pelaksanaan dari wakaf sering didengar dan dilihat adanya tanah wakaf yang diminta kembali oleh ahli waris wakif setelah wakif tersebut meninggal dunia. Kondisi ini pada dasarnya bukanlah masalah yang serius, karena apabila mengacu pada ketentuan peraturan perundang-undangan, wakaf dapat dilakukan untuk waktu tertentu, sehingga apabila waktu yang ditentukan telah terlampaui, wakaf dikembalikan lagi kepada ahli waris wakif. Namun khusus untuk wakaf tanah, ketentuan pembuatan akta ikrar wakaf telah menghapuskan kepemilikan hak atas tanah yang diwakafkan sehingga tanah yang diwakafkan tersebut tidak dapat diminta kembali. ${ }^{39}$ Selanjutnya mengenai dikuasainya tanah wakaf oleh nadzir secara turun temurun dan penggunaannya yang tidak sesuai dengan ikrar wakaf, hal ini dikarekan kurangnya pengawasan dari instansi yang terkait. Ahli waris atau keturunan nadzir beranggapan bahwa tanah tersebut milik nadzir, sehingga penggunaannya bebas sesuai kepentingan mereka sendiri. Persoalan ini diakibatkan kurangnya tingkat pemahaman ahli waris nadzir. ${ }^{40}$

\footnotetext{
${ }^{39}$ Devi Kurnia Sari, "Tinjauan Perwakafan Tanah Menurut Undang-Undang Nomor 41 Tahun 2004 tentang Wakaf di Kabupaten Semarang” Tesis (Semarang: Program Pascasarjana Universitas Diponegoro, 2006).

${ }^{40}$ Diah Ayuningtyas Putri Sari Dewi, Kekuatan Hukum Dan Perlindungan Hukum Terhadap Pemberian Wakaf Atas Tanah Di Bawah Tangan (Studi Pada Kecamatan Kedungwuni Kabupaten Pekalongan), Tesis (Semarang: Program Pascasarjana Universitas Diponegoro, 2010).
} 
Berdasarkan uraian tersebut bahwa alasan atau penyebab terjadinya sengketa wakaf adalah belum tertampungnya pengaturan tentang tanah wakaf yang banyak terjadi di Indonesia sebagaimana pada Undang-Undang Nomor 41 Tahun 2004, dan ironisnya ternyata masih banyak terdapat tanah yang tidak ditindaklanjuti dengan administrasi pembuatan akta ikrar wakaf, fenomena ditarik mintanya kembali tanah yang telah diwakafkan oleh para ahli waris wakif dan tanah yang telah dikuasai secara turun menurun sejak lama oleh ahli waris dikarenakan faktor pelanggaran dan tindak penyelewengan dari tujuan atas eksistensi pemanfaatan wakaf sebagaimana semula.

Beberapa sebab terjadinya sengketa di atas nampaknya sama dengan apa yang terjadi di Pondok Pesantren Al-Falah. Pondok Pesantren Al-Falah merupakan pusat pendidikan Islam yang mengajarkan tentang wawasan keIslaman kepada setiap santri yang hendak mengenyam pendidikan disana yang dilandasi sebuah kesadaran tentang pentingnya menjaga hubungan perdamaian antar sesama manusia dalam rangka mewujudkan cita-cita terbesar ajaran Islam sebagai rạ̣matan lil 'ālamīn. Oleh karena itu Pesantren Al-Falah selama ini dikenal sebagai pusat pendidikan yang jauh dari masalah, baik yang berasal dari dalam maupun dari luar pondok pesantren itu sendiri.

Menurut Maziatussaraf bahwa hal ihwal terjadinya sengketa tanah wakaf yang ada di Pondok Pesantren Al-Falah, yaitu bermula ketika dirinya mendengar sebuah kabar dari mulut ke mulut antar anggota keluarga dekat pondok pesantren yang mempermasalahkan status tanah yang hari ini sudah berdiri kokoh sebuah bangunan dan fasilitas pondok pesantren lainya. Menurut beberapa penuturan terungkap bahwa pihak ahli waris wakif merasa jika tanah yang sejatinya adalah tanah wakaf yang ada tersebut bukanlah tanah wakaf, sehingga pengelolaan dan hak pengakuan atas tanah tersebut masih ada pada pihak mereka. Mendengar akan hal ini maka ia segera mengklarifikasi masalah tersebut kepada pimpinan pondok pesantren selaku pihak yang di anggap lebih tau masalah status tanah yang diperselisihkan tersebut guna mencari jalan keluar atas kabar yang dapat mengganggu aktifitas pembelajaran dlingkungan pondok pesantren. ${ }^{41}$

\footnotetext{
${ }^{41}$ Maziatussaraf, Kepala Madrasah Tsanawiyah dan Ahli Waris, Wawancara, di Desa Tunggulo, tanggal 15 Juli 2012.
} 
Berangkat dari hasil musyawarah di lingkup internal pengelola tanah wakaf terbut disepakati untuk segera mengklarifikasi kepada para pihak yang di anggap memiliki kepentingan atas status tanah wakaf. Hal ini dilakukan dalam rangka memperjelas masalah yang beredar dan sekaligus mencari solusi agar kedapan tidak larut dalam masalah yang sama.

\section{b. Langkah Penyelesaian Sengketa Wakaf}

Perwakafan Pondok Pesantren Al-Falah dilaksanakan atas dasar saling percaya dan secara lisan saja. Sehingga, wakaf di sinipun menjadi wakaf di bawah tangan atau tidak tercatat. Oleh karena itu upaya penyelesaian sengketa dilakukan di bawah tangan pula. Penyelesaian di bawah tangan yang dimaksud adalah sebuah upaya penyelesaian tanpa ada pihak ketiga yang dalam pengertiannya pihak pengadilan. Jika dicermati bahwa penyelesaian sengketa wakaf di bawah tangan secara spesifik tidak diatur di dalam undang-undang tentang wakaf. Namun, apabila melihat dari beberapa uraian tentang penyelesaian sengketa di atas, maka jalan musyawarah atau perundingan sangatlah tepat dalam menyelesaikan sengketa wakaf di bawah tangan. Mengingat, persengketaan tentang wakaf ini tidak melibatkan campur tangan majelis hakim yang dalam hal ini persidangan.

Upaya yang dilakukan dalam penyelesaian sengketa wakaf di bawah tangan di Pondok Pesantren Al-Falah adalah dengan jalur musyawarah. Hal ini ditempuh dalam rangka menjaga fungsi dan hak pengelolaan tanah sebagaimana mestinya tanpa berpindah tangan pada pihak lain. Penyelesaian dengan jalur musyawarah itu sendiri telah diatur di dalam Undang-Undang Nomor 41 Tahun 2004 tentang Wakaf yang menyebutkan bahwa musyawarah adalah langkah awal untuk mencapai mufakat. Musyawarah memiliki posisi mendalam dalam kehidupan masyarakat Islam. Bukan sekadar sistem politik pemerintahan, tapi juga merupakan karakter dasar seluruh masyarakat. Seluruh persoalan didasarkan atas musyawarah, lalu dari masyarakat, prinsip ini merembes ke pemerintahan. Dalam Islam, musyawarah telah menjadi wacana yang sangat menarik. Hal itu terjadi karena istilah ini disebutkan dalam Alquran dan hadis, sehingga musyawarah secara tekstual merupakan fakta wahyu yang tersurat dan bisa menjadi ajaran normatif dalam Islam. Bahkan menjadi sesuatu yang 
sangat mendasar dalam kehidupan umat manusia, yang dalam setiap detik perkembangan umat manusia, musyawarah senantiasa menjadi bagian yang tidak terpisahkan di tengah perkembangan kehidupan umat manusia. ${ }^{42}$

Kedudukan musyawarah ini sangat agung di sisi Allah swt. Oleh karenanya Allah swt. memerintahkan rasul-Nya melakukannya melalui firman-Nya:

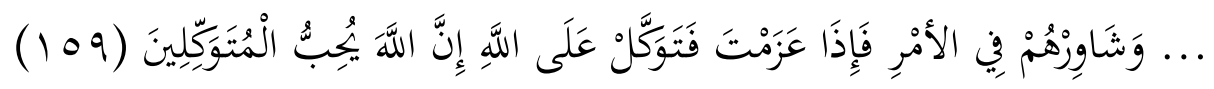

Terjemahnya:

Dan bermusyawarahlah dengan mereka dalam urusan itu. Kemudian, apabila engkau telah membulatkan tekad, maka bertakwallah kepada Allah. Sungguh, Allah mencintai orang yang bertawakkal (QS. Ali 'Imran/3: 159). ${ }^{43}$

Ayat ini merupakan perintah Allah kepada Nabi untuk berpegang kepadanya (musyawarah). Kalau Nabi sebagai orang yang ma'sum, diperintahkan untuk bermusyawarah dalam masalah urusan umat, maka umatnya sebagai manusia yang tidak maksum lebih-lebih lagi harus melakukan musyawarah. Ayat tersebut seakanakan berpesan kepada Rasulullah, bahwa musyawarah harus tetap dipertahankan dan dilanjutkan, walaupun terbukti pendapat yang pernah mereka putuskan keliru. Kesalahan mayoritas lebih dapat ditoleransi dan menjadi tanggung jawab bersama, dibandingkan dengan kesalahan seseorang meskipun diakui kejituan pendapatnya sekalipun. $^{44}$

Kaitannya dengan uraian di atas, maka dalam proses penyelesaian sengketa wakaf di Pondok Pesantren Al-Falah, pimpinan pondok pesantren mengawali langkah penyelesaiannya dengan mengundang seluruh ahli waris yang berjumlah 40 orang. Ahli waris ini merupakan anak dari 5 orang bersaudara yang telah mewakafkan sebagian hartanya kepada pondok pesantren. Setelah diundang dan duduk bersama dalam satu majelis pimpinan menjelaskan duduk persoalan tentang tanah wakaf tersebut. Menerangkan bahwa tanah tersebut benar telah diwakafkan oleh mendiang orang tua mereka demi pembangunan Pondok Pesantren Al-Falah. Tanah wakaf itu sendiri telah

\footnotetext{
${ }^{42}$ Syahrizal Abbas, Mediasi dalam Prespektif Hukum Syari'ah, Hukum Adat, dan Hukum Nasional (Cet. 1; Jakarta: Kencana Prenada Media Group, 2009), 229.

${ }^{43}$ Kementerian Agama RI., Ummum Mukminin: Al-Qur'an dan Terjemahan, 71.

${ }^{44}$ Muhammad Hanafi, "Kedudukan Musyawarah dan Demokrasi Di Indonesia," Jurnal Cita Hukum, Vol. 1, No. 2 (2013): 95-78.
} 
dipisahkan dari harta warisan dan telah disepakati bersama oleh 5 orang bersaudara yang merupakan mendiang orang tua mereka. Oleh karena itu, tanah yang telah diwakafkan ini tidak lagi dibagi dalam pembagian harta warisan dari orang tua para wakif. $^{45}$

Untuk menyikapi hal ini, maka ada 2 pilihan yang ditawarkan oleh pimpinan pondok yang dalam hal ini dianggap penentu kebijakan. Pertama, apabila para ahli waris yang keberatan tidak mengakui tanah tersebut sebagai tanah wakaf, maka pihak pondok pesantren bersedia membayar atau membeli tanah tersebut sesuai dengan harga Nilai Jual Objek Pajak (NJOP) di tahun itu. Adapun ketentuannya tanah wakaf ini akan dibagi sesuai dengan ilmu faraid (waris) kepada seluruh ahli waris dan dianggap sebagai pembagian harta warisan; Kedua, apabila seluruh ahli waris mengakui tanah tersebut sebagai tanah wakaf, maka pondok pesantren bersedia memberikan uang kerahiman atau santunan kepada para ahli waris yang dianggap kurang mampu. ${ }^{46}$

Hasil dari musyawarah ini adalah para ahli waris memilih pada pilihan kedua dari apa yang ditawarkan oleh pimpinan pondok pesantren, yaitu mengakui tanah tersebut sebagai tanah wakaf dan pemberian santunan kepada ahli waris yang kurang mampu sebagai wujud terima kasih pondok pesantren. Dari kesepakatan ini, telah dibuat surat pernyataan dari semua ahli waris tentang pengakuan atas tanah wakaf tersebut. Para ahli waris sepakat memilih opsi yang kedua, dan siap menandatangani surat pernyataan. Keputusan ini bagi kami adalah keputusan yang terbaik untuk menjaga nama baik pondok kedepannya. Surat pernyataan ini dibuat untuk bukti sebagai pegangan pengurus pondok dan akan segera diurus untuk pembuatan akta ikrar wakafnya $^{47}$

Menurut pimpinan pondok pesantren, Akta Ikrar Wakaf (AIW) belum dibuat namun surat pernyataan yang ditandatangani di atas materai tersebut bisa menjadi pegangan atau bukti hukum sementara. Ditegaskan oleh pimpinan pondok bahwa pemberian santunan kepada ahli waris yang dianggap kurang mampu bukanlah sebuah ganti rugi dari wakaf tersebut melainkan sebagai ucapan terima kasih pondok

\footnotetext{
${ }^{45}$ Khusnun Nizam, Ahli Waris, Wawancara, di Desa Tunggulo, tanggal 15 Juli 2012.

${ }^{46}$ Zainul Romiz Keosry, Pimpinan Pondok Pesantren Al-Falah, Wawancara, di Pesantren AlFalah), tanggal 17 Juli 2012.

${ }^{47}$ Ibid.
} 
pesantren. Hal ini ditegaskan karena, adanya niat sebagai ganti rugi atau pembayaran akan menyebabkan tanah wakaf tersebut menjadi batal. Keadaan inilah yang dihindari oleh kami. ${ }^{48}$ Olehnya itu bahwa pilihan yang kedua ini nampaknya sejalan dengan hadis Nabi yang terjemahannya berikut :

Telah bercerita kepada kami $A b u N u^{\prime}$ aim telah bercerita kepada kami Sufyan dari Sa'ad bin Ibrahim dari 'Amir bin Sa'ad dari ra. Berkata: Nabi saw. datang menjengukku (saat aku sakit) ketika aku berada di Makkah. Dia tidak suka bila meninggal dunia di negeri dimana dia sudah berhijrah darinya. Beliau bersabda; Semoga Allah merahmati Ibnu 'Afra'. Aku katakan: Wahai Rasulullah, aku mau berwasiat untuk menyerahkan seluruh hartaku. Beliau bersabda: Jangan. Aku katakan: setengahnya. Beliau bersabda: Jangan. Aku katakan lagi: Sepertiganya. Beliau bersabda: Ya, sepertiganya dan sepertiga itu sudah banyak. Sesungguhnya jika kamu meninggalkan ahli warismu dalam keadaan kaya itu lebih baik daripada kamu meninggalkan mereka dalam keadaan miskin lalu mengemis kepada manusia dengan menengadahkan tangan mereka. Sesungguhnya apa saja yang kamu keluarkan berupa nafkah sesungguhnya itu termasuk shadaqah sekalipun satu suapan yang kamu masukkan ke dalam mulut istrimu. Dan semoga Allah mengangkatmu dimana Allah memberi manfaat kepada manusia melalui dirimu atau memberikan madharat orang-orang yang lainnya. Saat itu dia (Sa'ad) tidak memiliki ahli waris kecuali seorang anak perempuan. ${ }^{49}$

Hadis di atas bercerita tentang keutamaan seorang pewaris yang meninggalkan ahli warisnya dalam keadaan kaya atau berkecukupan dibandingkan dalam keadaan miskin. Hal ini, sepertinya dikehendaki oleh pengurus Pondok Pesantren Al-Falah dengan memberikan santunan kepada ahli waris yang kurang mampu tadi. Sehingga, keutamaan bagi pewaris seperti yang tertuang dalam hadist di atas bisa terpenuhi, terlepas dari nasib atau jalan hidup yang telah ditetapkan oleh Allah Swt. Adapun pembelian atas benda wakaf yang tidak dikehendaki oleh pimpinan pondok di atas, sejalan dengan apa yang dikemukakan oleh Imam Syafi'i bahwa harta wakaf tidak bisa dibeli dan diwariskan. Apabila hal ini terjadi maka status harta wakaf menjadi batal. ${ }^{50}$

Mencermati pemaparan di atas, maka kesimpulannya bahwa dalam proses penyelesaian sengketa melalui jalur musyawarah bertujuan menciptakan perdamaian di

\footnotetext{
${ }^{48}$ Ibid.

${ }^{49}$ Imam Abu Abdullah Muhammad bin Ibrahim bin al-Mughirah bin Bardazabah, Shahih Bukhari (Beirut: Percetakan Darul Fikri, 2010), 31.

${ }^{50}$ Muammar Alay Idrus, "Keabsahan, Kepastian Hukum Dan Perlindungan Hukum Atas Perwakafan Yang Tidak Tercatat (Studi Kasus Praktek Perwakafan Tanah Di Kecamatan Sukamulia)," Jurnal IUS: Kajian Hukum dan Keadilan, Vol. 5, No. 1 (2017): 30-48.
} 
lingkungan para pihak yang bersengketa. Jalur musyawarah juga memperhatikan hak dari masing-masing pihak bersengketa.

\section{E. Kesimpulan}

Prosedur pelaksanaan wakaf di Pondok Pesantren Al-Falah pada mulanya dilakukan berdasarkan pada prinsip saling percaya tanpa ada unsur keraguan, namun di kemudian hari ternyata menimbulkan masalah, sehingga perjanjian serah terima tanah wakafpun tidak dilakukan. Jalan yang ditempuh dalam penyelesaian sengketa wakaf di Pondok Pesantren Al-Falah adalah dengan jalur musyawarah. Hal ini lebih efektif baik dari segi pertimbangan hubungan kekeluargaan juga demi menjaga nama baik keluarga. Adapun langkah musyawarah yang ditempuh itu melahirkan sebuah solusi yakni setiap ahli waris yang dianggap kurang mampu mendapatkan santunan kerahiman dari pihak pondok pesantren. Santunan kerahiman ini dianggap sebagai bentuk terima kasih pihak pondok pesantren kepada ahli waris. Dan tidak di anggap sebagai pengganti kerugian atas tanah wakaf. Karena jika hal ini terjadi, maka status tanah wakaf menjadi batal, dan hal inilah yang sangat dijaga oleh pondok pesantren guna melanjutkan niat ikhlas para pendahulunya.

Untuk menjaga hubungan baik antar pihak yang bersengketa langkah musyawarah kiranya dapat ditempuh tanpa harus menempuh jalur pengadilan. Artinya, setiap persengketaan tidak harus diselesaikan pada proses persidangan. Sebuah perwakafan yang dilakukan di bawah tangan atau tidak tercatat oleh pihak yang berwenang, sangat rentan akan masalah atau sengketa di kemudian hari. Oleh karena itu, bagi pihak-pihak yang mau mewakafkan sebagian hartanya hendaknya memperhatikan legalitas dan syarat administratif sebagaimana yang diatur oleh peraturan Negara agar harta wakaf memiliki status yang jelas dan sesuai dengan peruntukannya, sehingga kedepannya tidak menimbulkan berbagai sengketa atau permasalahan.

\section{Daftar Pustaka}

Abbas, Syahrizal. Mediasi dalam Prespektif Hukum Syari'ah, Hukum Adat, dan Hukum Nasional. Cet. 1; Jakarta: Kencana Prenada Media Group, 2009. 
Adam, Siti Megadianti, Takdir Rahmadi. "Sengketa dan Penyelesaiannya" Buletin Musyawarah Nomor 1 (Jakarta: Indonesia Center For Law, 1997, dalam Rahmadi Usman, Pilihan Penyelesaian Sengketa di Luar Pengadilan. Bandung: Citra Aditya Bakti, 2003.

Al-Bahuti, Mansyur bin Yunus bin Idris. Kasysyafa al-Qina' an Matn al-Iqnā. Bairut: Dar al-Kutub al-Ilmiyah, t.th.

Al-Baijuri, Syaikh Ibrahim Hasyiyah al-Baijuri, Juz 2. Bairut: Dar al-Fikr, t.th..

Al-Bukhārī, Abū 'Abd Allāh Muḥammad ibn Ismā'īl ibn Ibrāhīm ibn al-Mughīrah ibn Bardizbah al-Ju'fī. Șaḥih Bukhārī. Beirut: Dar al- Fikr, 1981.

Darwis, Rizal. "Pemikiran Ibnu Qayyim al-Jauziyah terhadap Paradigma Perubahan Hukum," Adzkiya: Jurnal Hukum dan Ekonomi Islam, Vol. 5, No. 1 (2017).

Departemen Agama, Fiqih Wakaf. Jakarta: Proyek Peningkatan Pemberdayaan Wakaf, Direktorat Jenderal Bimbingan Masyarakat Islam dan Penyelenggara Haji, 2004.

Dewi, Diah Ayuningtyas Putri Sari. "Kekuatan Hukum Dan Perlindungan Hukum Terhadap Pemberian Wakaf Atas Tanah Di Bawah Tangan (Studi Pada Kecamatan Kedungwuni Kabupaten Pekalongan)," Tesis. Semarang: Program Pascasarjana Universitas Diponegoro, 2010.

Al-Dimasqi, Taqiy al-Din Abi Bakr Ibn Muhammad al-Husaini. Kifayat al-Akhyar fi Hall Gayat al-Ikhtishar, Juz 1. Semarang: Toha Putra, t.th.

Al-Dimasyqi, Al-Imam Muhyiddin Abu Zakariya bin Syaraf al-Nawawi. Ar-Raudhah, Juz 2 (Bairut: Dar al-Kutub al-Ilmiah, t.th.

Fadhilah, Nur. "Sengketa Tanah Wakaf Dan Strategi Penyelesaiannya," De Jure: Jurnal Hukum dan Syar'iah, Vol. 3, No. 1 (2011).

Al-Hanafi, Ibn al-Humam. Syarah Fath al-Qadir, Jilid 6. Bairut: Darr al-Kutub alIlmiyah, 1995.

Hanafi, Muhammad. "Kedudukan Musyawarah dan Demokrasi Di Indonesia," Jurnal Cita Hukum, Vol. 1, No. 2 (2013).

Hermawan, Wawan. "Politik Hukum Wakaf di Indonesia," Jurnal Pendidikan Agama Islam-Ta'lim, Vol. 12, No. 2 (2014).

Ibn Anas, Malik. Al-Mudawwanah al-Kubra, Juz 4. Bairut: Dar al-Kutub al-Ilmiyah, t.th.

Ibn Bardazabah, Imam Abu Abdullah Muhammad bin Ibrahim bin al-Mughirah. Shahih Bukhari (Beirut: Darul Fikri, 2010.

Ibn Hajjaz, Imam Abi Husain Muslim. Shahih Muslim, Juz 3. Bairut: Darul Kitab alAlamiyyah, t.th.

Ibn Qudamah, Al-Mughni, Juz 5. Riyadh: Maktabah al-Riyadh al-Haditsiyah, 1941. 
Idrus, Muammar Alay. "Keabsahan, Kepastian Hukum Dan Perlindungan Hukum Atas Perwakafan Yang Tidak Tercatat (Studi Kasus Praktek Perwakafan Tanah Di Kecamatan Sukamulia)," Jurnal IUS: Kajian Hukum dan Keadilan, Vol. 5, No. 1 (2017).

Al-Kabisi, Muhammad Abid. Ahkam Al-Waqf fi Al-Syari'ah Al-Islamiyah, terj. Ahrul Sani Fathurraham dan Kuwais, Hukum Wakaf. Cet. 1; Depok: Iman Press, 2004.

Kementerian Agama RI., Ummum Mukminin: Al-Qur'an dan Terjemahan untuk Wanita. Ciputat: Penerbit Wali, 2010.

Al-Khatib, Muhammad. Al-Iqna’. Bairut: Darul Ma'rifah, t.th.

Laldin, Mohamad A., Mek Wok Mahmud, and Mohd Fuad Sawari, "Maqasid Syariah Dalam Pelaksanaan Waqaf," Jurnal Pengurusan Jawhar, Vol. 2, No. 2 (2008).

Mahamood, Siti M. "Pembentukan Dana Wakaf Menurut Perspektif Syariah Dan Undang-Undang Serta Aplikasinya di Malaysia," Jurnal Syariah, Vol. 15, No. 2 (2007).

Malibari, Zainuddin. Fathul Mu'in (Surabaya: Al-Haromain Jaya Indonesia, t.th.

Munir, Akhmad Sirojudin. "Optimalisasi Pemberdayaan Wakaf Secara Produktif," Ummul Qura, Vol. 6, No 2 (2018).

Al-Nawawi, Abu Zakaria Muhyiddin Yahya bin Sharaf. Kitab al-Majmu alMuhadzdzab, Juz 16. T.tp: Dar Ihya al-Turats al-Arabi, 1995.

Nurhidayani, Muaidy Yasin, dan Busaini Busaini, "Pengelolaan Dan Pemanfaatan Wakaf Tanah dan Bangunan," Maqdis: Jurnal Kajian Ekonomi Islam, Vol. 2, No. 2 (2017).

Republik Indonesia. Undang-Undang Nomor 41 Tahun 2004 tentang Wakaf.

Sari, Devi Kurnia. “Tinjauan Perwakafan Tanah Menurut Undang-Undang Nomor 41 Tahun 2004 tentang Wakaf di Kabupaten Semarang" Tesis. Semarang: Program Pascasarjana Universitas Diponegoro, 2006.

Shihab, M. Quraisy. Mukjizat Al-Qur'an. Cet. 2; Bandung: Mizan, 1997.

Al-Syafi'i, Muhammad Ibn Idris. Al-Umm, Juz 3. Mesir: Maktabah Kuliyah alAzhariyah, t.th.

Al-Syarbini, Al-Imam Syamsuddin Muhammad bin Muhammad al-Khathib. Mughni al-Muhtaj (Kairo: Mushthafa Habibi, t.th.

Zuhaili, Wahbah. Al-Fiqhu al-Islami wa 'Adillatuhu. Damaskus: Dar al-Fikr alMu'ashir, t.th. 